\title{
Redox active dendronized polystyrenes equipped with peripheral triarylamines
}

\author{
Toshiki Nokami§, Naoki Musya, Tatsuya Morofuji, Keiji Takeda, Masahiro Takumi, \\ Akihiro Shimizu and Jun-ichi Yoshida*
}

\author{
Letter \\ Address: \\ Department of Synthetic Chemistry and Biological Chemistry, \\ Graduate School of Engineering, Kyoto University, Nishikyo-ku, Kyoto \\ 615-8510, Japan \\ Email: \\ Jun-ichi Yoshida* - yoshida@sbchem.kyoto-u.ac.jp \\ * Corresponding author \\ $\S$ Present address: Department of Chemistry and Biotechnology, \\ Graduate School of Engineering, Tottori University, 4-101 Koyama- \\ chominami, Tottori 680-8552, Japan \\ Keywords: \\ carbocation; cross-coupling; dendrimer; dendronized polymer; redox
}

\author{
Beilstein J. Org. Chem. 2014, 10, 3097-3103. \\ doi:10.3762/bjoc. 10.326 \\ Received: 30 October 2014 \\ Accepted: 10 December 2014 \\ Published: 22 December 2014 \\ This article is part of the Thematic Series "Electrosynthesis". \\ Guest Editor: S. R. Waldvogel \\ (c) 2014 Nokami et al; licensee Beilstein-Institut. \\ License and terms: see end of document.
}

\begin{abstract}
Dendronized polystyrene having peripheral bromo groups was prepared from the dendronization of unfunctionalized polystyrene with dendritic diarylcarbenium ions bearing peripheral bromo groups using the "cation pool" method. The palladium-catalyzed amination of the peripheral bromo groups with diarylamine gave dendronized polystyrene equipped with peripheral triarylamines, which exhibited two sets of reversible redox peaks in the cyclic voltammetry curves.
\end{abstract}

\section{Introduction}

Assembling small functional molecules using dendrimers [1] and dendronized polymers [2-8] as scaffolds serves as a useful method for synthesizing organic functional materials having nanosize three-dimensional structures. Although there are many examples of redox-active dendrimers, including those equipped with ferrocene [9,10], triarylamines [11-14], and tetrathiafulvalene (TTF) derivatives [15-19], the corresponding dendronized polymers are rare [20]. One of the major reasons for this seems to be the difficulty in making such structures. However, redoxactive dendronized polymers should provide more opportuni- ties to form functional organic materials, and therefore, the development of efficient methods for the synthesis of redoxactive dendronized polymers is highly desirable. Recently, we have developed a new method [21-26] for the synthesis of dendronized polymers [27] from the dendronization of unfunctionalized polystyrenes with electrogenerated dendritic diarylcarbenium ions. The simplicity and step economy of this method prompted us to synthesize dendronized polymers equipped with peripheral functional groups by the use of this method. 
In principle, there are two synthetic approaches for synthesizing peripherally functionalized dendronized polystyrenes: (a) the functionalization of dendronized polystyrene (the "graft from" approach, Figure 1a); and (b) dendronization of polystyrenes with the dendritic carbocation equipped with functional groups (the "graft to" approach, Figure 1b). Both approaches have advantages and disadvantages. In the former case, more dendritic scaffolds can be introduced by functionalization, but structural inhomogeneity can occur from incomplete peripheral functionalization. In the latter approach, direct dendronization by the functionalized diarylcarbenium ions may be difficult, although the dendritic substituents would have a uniform structure. In this paper we report on the synthesis of redox-active dendronized polystyrenes via the peripheral modification of dendronized polystyrene [28].

\section{Results and Discussion}

Dendrimer 4 , having a bromo functionality was prepared on a multigram scale, as shown in Figure 2. Di(p-bromophenyl)carbinol (1) was treated with $\mathrm{SOCl}_{2}$ to obtain $\operatorname{di}(p$ bromophenyl)methyl chloride (2) in quantitative yield. A Friedel-Crafts-type alkylation [29] of diphenylsilane $\mathbf{3}$ with $\mathbf{2}$ in the presence of boron trifluoride etherate as a Lewis acid gave 4 in $86 \%$ yield. The oxidation potential of $4\left(E_{\mathrm{ox}}=1.17 \mathrm{~V}\right.$ vs $\mathrm{SCE}$ ) is slightly lower than that of the fluorine analogue

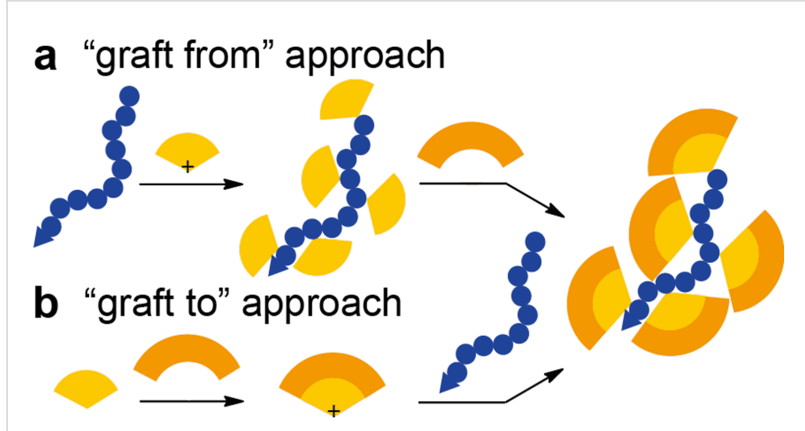

Figure 1: Two synthetic approaches toward the peripherally functionalized dendronized polystyrenes (blue dotted line = polystyrene, orange sector $=$ dendron of the 1 st generation, dark orange sector $=$ dendron of the 2 nd generation). (a) Peripheral functionalization of the dendronized polystyrene ("graft from" approach). (b) Dendronization with dendritic diarylcarbenium ions equipped with functional groups (“graft to" approach).

( $E_{\mathrm{ox}}=1.25 \mathrm{~V}$ vs SCE) which was used as a precursor of the dendritic cation in our previous work [25], indicating that bromine analogue 4 can act as a precursor of the dendritic cation.

The functionalization of $\mathbf{4}$ was examined before studying the functionalization of dendronized polystyrene. Thus, $\operatorname{di}(p-$ methoxyphenyl)amino groups were introduced to 4 using a<smiles>CCOC(C)(c1ccccc1)c1ccccc1C(SC)c1ccc(Br)cc1</smiles>

1

2<smiles>CSC(c1ccc(C(c2ccc(Br)cc2)c2ccc(Br)cc2)cc1)c1ccc(C(c2ccc(Br)cc2)c2ccc(Br)cc2)cc1</smiles>

$4 \quad\left(E_{\text {ox }}=1.17 \mathrm{~V} \text { vs SCE }\right)^{a}$

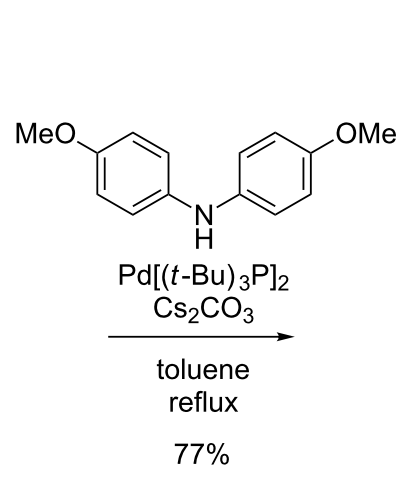

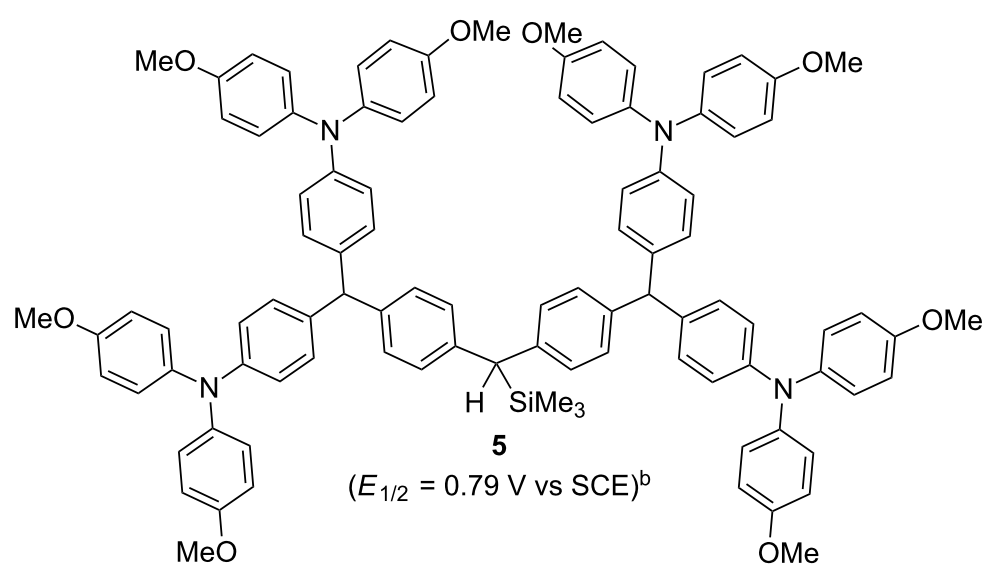

Figure 2: Preparation of the dendrimer having peripheral bromo groups and their conversion to diarylamino groups. ${ }^{\mathrm{a} O x d a t i o n}$ potential $\left(E_{\mathrm{ox}}\right) .{ }^{\mathrm{b}} \mathrm{Redox}$ potential $\left(E_{1 / 2}\right)$. 
Buchwald-Hartwig amination [11]. The choice of a base is crucial for this transformation, and the transformation was successfully carried out using $\mathrm{Cs}_{2} \mathrm{CO}_{3}$ as a base and $\operatorname{Pd}\left[\mathrm{P}(t-\mathrm{Bu})_{3}\right]_{2}$ as a catalyst [30] to obtain the dendrimer 5 having peripheral diarylamino groups in a yield of $77 \%$. Compound 5 can serve as the precursor of dendritic diarylcarbenium ions having peripheral triarylamine structures. However, its redox potential $\left(E_{1 / 2}=0.79 \mathrm{~V}\right.$ vs SCE $)$ is much lower than the oxidation potential of dendrimer 4 , indicating that the triarylamine moiety is oxidized before the benzylsilane moiety. Using the "graft to" approach to synthesize peripherally functional- ized dendronized polystyrene (Figure 1b) employing 5 as a precursor of the dendritic carbocation was unsuccessful. Lowtemperature electrochemical oxidation of dendrimer 5 using the "cation pool" method [31-47] did not give the corresponding dendritic diarylcarbenium ion even, when subjected to excess capacitance (up to $5.0 \mathrm{~F} / \mathrm{mol}$ ).

Next, we examined the "graft-from" approach (Figure 3). The low-temperature electrochemical oxidation of dendrimer 4 using the "cation pool" method was performed in $\mathrm{CD}_{2} \mathrm{Cl}_{2}$, and the resulting anodic solution was transferred to NMR tubes.<smiles>O=C(O)c1ccc(C(c2ccc(Br)cc2)c2ccc(C(c3ccc(Br)cc3)c3ccc(Br)cc3)cc2)cc1</smiles><smiles>CCC(CC)C(CC)C(CC)c1ccc(C(c2ccc(C(c3ccc(Br)cc3)c3ccc(Br)cc3)cc2)c2ccc(C(c3ccc(Br)cc3)c3ccc(Br)cc3)cc2)cc1</smiles>

$\mathbf{8 a} / \mathbf{8 b}$

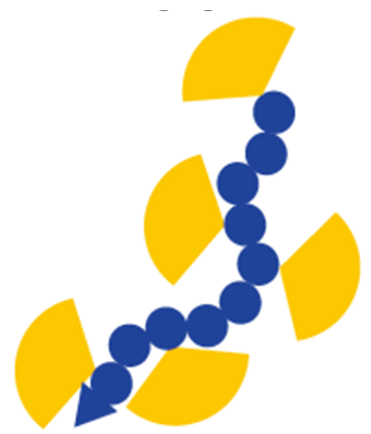

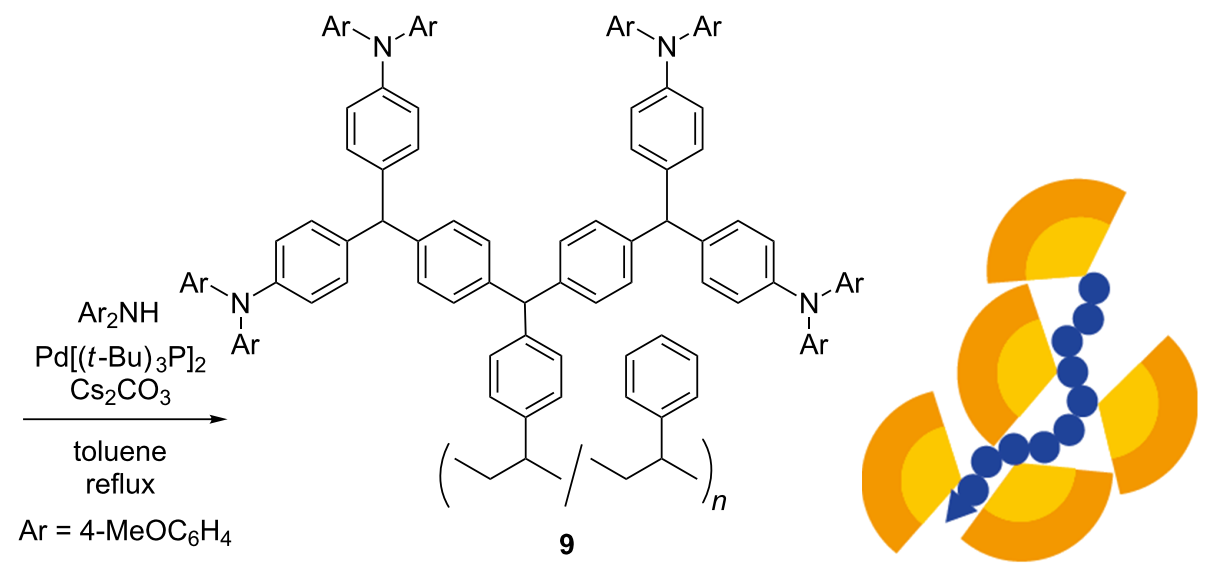


Low-temperature NMR analysis indicated that an accumulation of dendritic diarylcarbenium ion $\mathbf{6}$ in the solution had occurred. The chemical shift of the cationic carbon $\left({ }^{13} \mathrm{C}\right.$ NMR $\delta$ 194.8) and that of the proton attached to the cationic carbon $\left({ }^{1} \mathrm{H}\right.$ NMR $\delta 9.93$ ) indicated that there was no interaction between the cationic carbon and peripheral bromo groups, because the chemical shifts were almost identical to those of the fluorine analogue $\left({ }^{13} \mathrm{C}\right.$ NMR $\delta 194.4,{ }^{1} \mathrm{H}$ NMR $\delta$ 9.92) [25].

The reaction of $\mathbf{6}$ (generated on a preparative scale in $\mathrm{CH}_{2} \mathrm{Cl}_{2}$ ) with a low-molecular weight polystyrene $7 \mathbf{a}\left(M_{\mathrm{n}}=1,580\right.$, polydispersity index $(\mathrm{PDI})=1.04,22 \mathrm{mg}$ ) was performed at $0{ }^{\circ} \mathrm{C}$ (Figure 3). The resulting dendronized polystyrene $8 \mathbf{a}$ was characterized using MALDI-TOF MS analysis. Six peak groups were observed, as shown in Figure 4. The peak occurring at $10,573 \mathrm{Da}\left[\mathrm{M}+\mathrm{Ag}^{+}\right]$is derived from 11 dendritic substituents $(815 \mathrm{Da} \times 11), 14$ styrene units $(103 \mathrm{Da} \times 11+104 \mathrm{Da} \times 3)$, and a butyl group ( $58 \mathrm{Da}$ ), which was derived from the initiator at the end of the polystyrene. The broader peaks seem to be attributable to two isotopes of the bromo groups (79 and $81 \mathrm{Da}$ ), and the small peak separation 101-103 Da is consistent with the molecular weight of styrene monomer (104 Da). The MS analysis indicated that 6 reacted with about $80 \%$ of the phenyl groups on polystyrene $7 \mathbf{a}$. This ratio is consistent with the

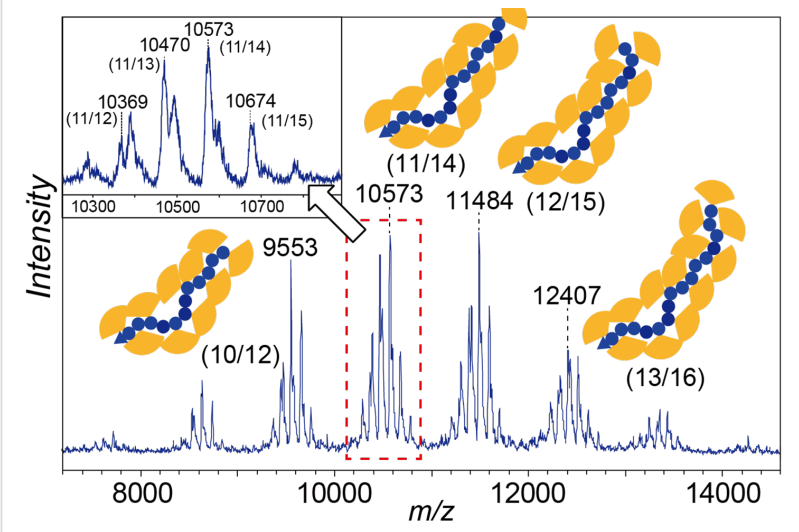

Figure 4: MALDI-TOF MS analysis of the dendronized polystyrene with peripheral bromo groups. implemented rate $(77 \%)$ calculated from the increase in weight of the polystyrene (22 $\mathrm{mg}$ to $150 \mathrm{mg}$ ).

In a similar manner, dendronized polystyrene $\mathbf{8 b}$ was synthesized from polystyrene having a longer chain length $\mathbf{7 b}$ $\left(M_{\mathrm{n}}=9,300, \mathrm{PDI}=1.02\right)$. Using GPC analysis to estimate the molecular weight of the dendronized polymer was not appropriate, because both the $M_{\mathrm{n}}$ and $M_{\mathrm{w}}$ values of the obtained dendronized polystyrene $\mathbf{8 b}$ were only twice that of the starting polystyrene $7 \mathbf{b}$ (Table 1). SEC-MALLS analysis indicated that 6 reacted with about $70 \%$ of the phenyl groups on polystyrene 7b. This ratio is slightly larger than the implemented rate (55\%) calculated from the increase in weight of the polystyrene (156 mg to $820 \mathrm{mg}$ ).

The peripheral bromo groups of $\mathbf{8 b}$ were converted to diarylamino groups using a Hartwig-Buchwald amination employing $\operatorname{Pd}\left[\mathrm{P}(t-\mathrm{Bu})_{3}\right]_{2}(10 \mathrm{~mol} \%)$ and $\mathrm{Cs}_{2} \mathrm{CO}_{3}$ (12 equiv) to obtain 9. Dendronized polystyrene 9 was also analyzed using GPC and SEC-MALLS measurements employing DMF as an eluent. The results are summarized in Table 1. GPC analysis indicated either a slight increase or no increase in molecular weight from the peripheral functionalization, but SEC-MALLS measurements showed an identifiable increase in the molecular weight ( $M_{\mathrm{W}}=62,000$ to 226,000 ), which is more than double the theoretical value $\left(M_{\mathrm{W}}=100,000\right.$ after $100 \%$ conversion of the peripheral bromo groups to diarylamino groups). Although the PDI did not change appreciably after dendronization (7b to $\mathbf{8 b}$ ), the PDI increased slightly after peripheral functionalization $(\mathbf{8 b}$ to 9). Presently, the ratio of methine protons in the focal points of the dendritic structure ( $\delta 5.38-5.00$, broad singlet, $3 \mathrm{H})$ and the methyl protons of the peripheral methoxy groups ( $\delta 3.80-3.40$, broad singlet, $24 \mathrm{H}$ ) in the ${ }^{1} \mathrm{H}$ NMR spectra is the only evidence for the conversion of the peripheral bromo groups to diarylamino groups. The observed ratio was 1:8.4 (methane/methyl), which indicates a quantitative conversion (theoretical ratio is $1: 8$ ).

The redox behavior of 9 was studied by means of cyclic voltammetry (CV, Figure 5). Compound 9 showed two sets of revers-

Table 1: Molecular weight analyses of the dendronized polystyrenes.

\begin{tabular}{|c|c|c|c|c|c|c|}
\hline \multirow[t]{2}{*}{ polymer } & \multicolumn{3}{|c|}{ GPC } & \multicolumn{3}{|c|}{ SEC-MALLS } \\
\hline & $M_{\mathrm{n}}$ & $M_{\mathrm{w}}$ & PDI & $M_{\mathrm{n}}$ & $M_{\mathrm{w}}$ & PDI \\
\hline $7 b^{a}$ & 9,300 & 9,490 & 1.02 & - & - & - \\
\hline $8 b$ & 18,800 & 19,900 & 1.06 & 59,400 & 62,000 & 1.04 \\
\hline 9 & 18,200 & 22,100 & 1.21 & 175,800 & 226,000 & 1.29 \\
\hline
\end{tabular}

apolymer $\mathbf{7 b}$ was analyzed only by GPC. 


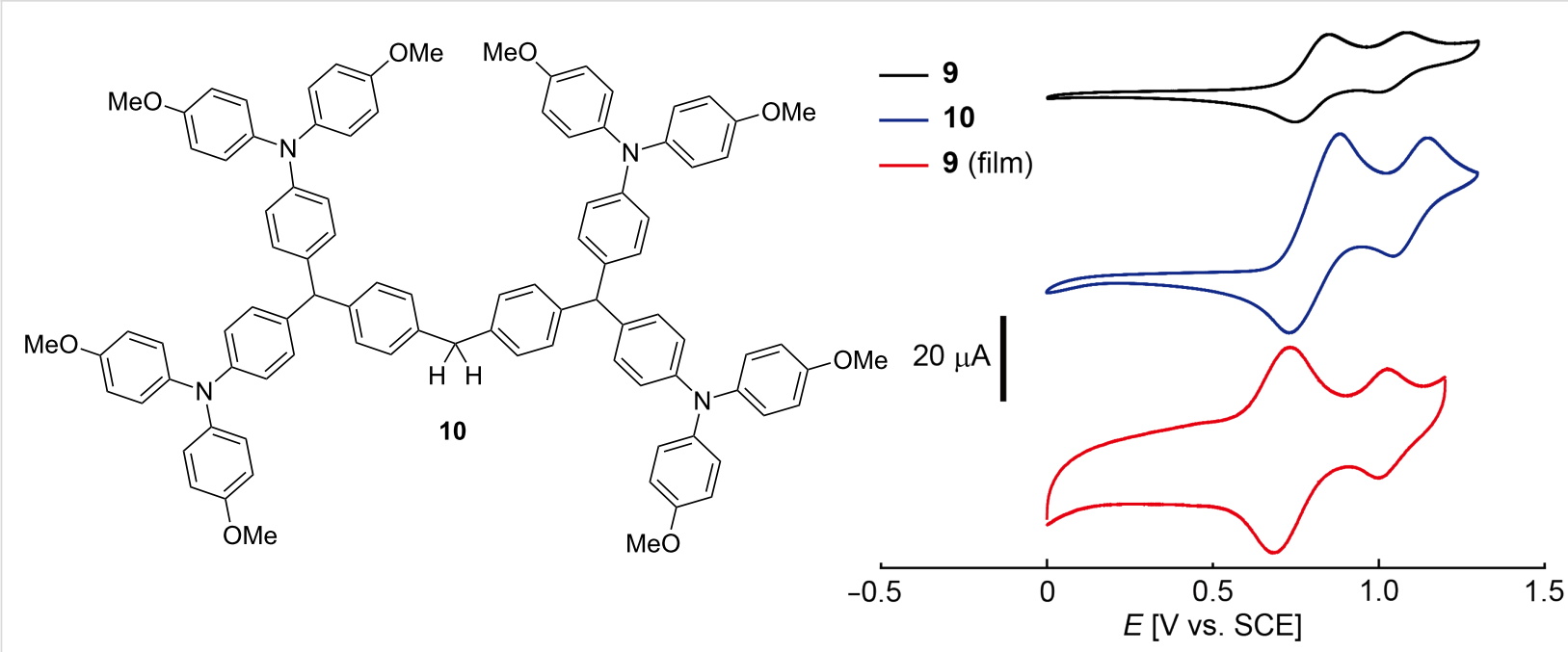

Figure 5: Cyclic voltammograms of dendronized polystyrene 9 (black line), model compound 10 (blue line), and the film of dendronized polystyrene 9 (red line). See the Experimental section for the details.

ible redox peaks $\left(E_{1 / 2}=0.80\right.$ and $1.04 \mathrm{~V}$ vs SCE), although it has been reported that $\mathrm{di}(p$-methoxyphenyl)phenylamine shows a single redox peak in its CV curves [48]. Therefore, the two sets of redox peaks of 9 seem to be ascribable to the interaction of the initially formed radical cation from the triarylamine moiety with a neighboring neutral triarylamine moiety, which disfavors the second electron transfer from the latter, although the details of this reaction are not clear as yet $[49,50]$. This is consistent with the observation that dendrimer $\mathbf{1 0}$ prepared by desilylation of $\mathbf{5}$ followed by amination (see Supporting Information File 1 for preparative details) showed two reversible waves occurring at similar potentials $\left(E_{1 / 2}=0.81\right.$ and $1.10 \mathrm{~V}$ vs SCE) (Figure 5, blue line).

A film of dendronized polystyrene 9 was prepared on a Pt plate electrode as a film by drop casting of a $\mathrm{CH}_{2} \mathrm{Cl}_{2}$ solution of $\mathbf{9}$. The redox behavior of the film of 9 on a Pt electrode was analyzed using CV (Figure 5, red line). Reversible CV cycles $\left(E_{1 / 2}=0.76\right.$ and $1.01 \mathrm{~V}$ vs SCE) were obtained in a mixed solvent $\left(\mathrm{CH}_{3} \mathrm{CN} /\right.$ toluene $\left.1: 3\right)$ using $\mathrm{Bu}_{4} \mathrm{NB}\left(\mathrm{C}_{6} \mathrm{~F}_{5}\right)_{4}$ as the electrolyte. The small shifts in the redox peaks from those obtained from solution may be attributable to the changes in solvent and electrolyte. The peak separations for a film of 9 $\left(\Delta E\left(E_{\mathrm{ox}}-E_{\mathrm{red}}\right)=52\right.$ and $\left.27 \mathrm{mV}\right)$ are significantly smaller than those observed for a solution of $9(\Delta E=103$ and $87 \mathrm{mV})$, indicating immobilization of 9 occurred on the surface of the electrode.

\section{Conclusion}

In conclusion, redox-active dendronized polystyrene was successfully synthesized by peripheral functionalization of dendronized polystyrene having peripheral bromo groups with diarylamines. Thus, dendronized polystyrene having peripheral bromo groups may serve as a versatile precursor of dendronized polystyrenes equipped with various functional groups. Dendronized polystyrene having peripheral diarylamino groups showed reversible redox behavior in both solution and as a film deposited on an electrode. Further optimization of the present method and applications of peripheral functionalization of dendronized polystyrenes are under investigation in our laboratory.

\section{Experimental \\ Electrochemical analyses}

Electrochemical analysis was performed using an ALS/ Chi700DS electrochemical analyzer. A saturated calomel electrode (SCE) (RE-2B, ALS Co. Ltd.) was used as the reference electrode.

The oxidation potential $\left(E_{\mathrm{ox}}\right)$ of dendrimer 4 was measured using linear sweep voltammetry employing a gassy carbon (GC) rotating disk electrode (diameter $=3.0 \mathrm{~mm}$, ALS Co. Ltd.) and a Pt wire counter electrode at room temperature. $\mathrm{CH}_{2} \mathrm{Cl}_{2}$ was used as a solvent and $\mathrm{Bu}_{4} \mathrm{NBF}_{4}(0.1 \mathrm{M})$ was used as a supporting electrolyte. The scan rate was $100 \mathrm{mV} / \mathrm{s}$.

The redox potentials $\left(E_{1 / 2}\right)$ of $\mathbf{5}$ and $\mathbf{1 0}$, and that of dendronized polystyrene 9 were measured by cyclic voltammetry (CV) using a GC working electrode (diameter $=3.0 \mathrm{~mm}$, ALS Co. Ltd.) and a Pt wire counter electrode at room temperature. $\mathrm{CH}_{2} \mathrm{Cl}_{2}$ was used as a solvent and $\mathrm{Bu}_{4} \mathrm{NBF}_{4}(0.1 \mathrm{M})$ was used as a supporting electrolyte. The scan rate was $100 \mathrm{mV} / \mathrm{s}$. The $\mathrm{GC}$ electrode was polished with alumina powder $(0.05 \mu \mathrm{m})$ in water using a polishing pad, water-washed, and air-dried before use. 
Cyclic voltammetry of a film of $\mathbf{9}$ deposited on a Pt plate electrode was measured as follows: Dendronized polystyrene $\mathbf{9}$ was deposited on a Pt plate electrode $\left(1 \times 1 \mathrm{~cm}^{2}\right)$ as a film by drop casting of a $\mathrm{CH}_{2} \mathrm{Cl}_{2}$ solution of $\mathbf{9}$, and the solvent was evaporated under reduced pressure to obtain the film of 9 attached to the Pt plate. The CV measurement was performed using the $\mathrm{Pt}$ plate with the film of 9 as the working electrode and a $\mathrm{Pt}$ wire counter electrode at room temperature. A mixer of $\mathrm{CH}_{3} \mathrm{CN} /$ toluene (1:3) was used a solvent and $\mathrm{Bu}_{4} \mathrm{NB}\left(\mathrm{C}_{6} \mathrm{~F}_{5}\right)_{4}(0.1 \mathrm{M})$ as a supporting electrolyte. The scan rate was $100 \mathrm{mV} / \mathrm{s}$.

\section{Supporting Information}

\section{Supporting Information File 1}

Experimental procedures for the synthesis of new compounds and spectral data of new compounds including ${ }^{1} \mathrm{H}$ NMR, ${ }^{13} \mathrm{C}$ NMR, and HMQC spectra. [http://www.beilstein-journals.org/bjoc/content/ supplementary/1860-5397-10-326-S1.pdf]

\section{Acknowledgements}

The authors gratefully acknowledge partial financial supports from Grants-in-Aid for Scientific Research on Innovative Areas (No. 2105) from the MEXT and Young Scientists (B) (No. 23750127) from the JSPS. T. N. thanks the Asahi Glass Foundation for financial support. The authors thank Prof. Mitsuo Sawamoto and Dr. Takaya Terashima of Kyoto University for SCE-MALLS measurements and Dr. Keiko Kuwata of Kyoto University for MS analyses.

\section{References}

1. Grayson, S. M.; Fréchet, J. M. J. Chem. Rev. 2001, 101, 3819-3868. doi:10.1021/cr990116h

2. Schlüter, A. D.; Rabe, J. P. Angew. Chem., Int. Ed. 2000, 39, 864-883. doi:10.1002/(SICI)1521-3773(20000303)39:5<864::AID-ANIE864>3.0. CO;2-E

3. Schlüter, A. D. J. Polym. Sci., Part A: Polym. Chem. 2001, 39, 1533-1556. doi:10.1002/pola.1130

4. Zhang, A.; Shu, L.; Bo, Z.; Schlüter, A. D. Macromol. Chem. Phys. 2003, 204, 328-339. doi:10.1002/macp.200290086

5. Frauenrath, H. Prog. Polym. Sci. 2005, 30, 325-384. doi:10.1016/j.progpolymsci.2005.01.011

6. Lee, C. C.; MacKay, J. A.; Fréchet, J. M. J.; Szoka, F. C. Nat. Biotechnol. 2005, 23, 1517-1526. doi:10.1038/nbt1171

7. Rudick, J. G.; Percec, V. Acc. Chem. Res. 2008, 41, 1641-1652. doi:10.1021/ar800086w

8. Rosen, B. M.; Wilson, C. J.; Wilson, D. A.; Peterca, M.; Imam, M. R.; Percec, V. Chem. Rev. 2009, 109, 6275-6540. doi:10.1021/cr900157q

9. Valério, C.; Fillaut, J.-L.; Ruiz, J.; Guittard, J.; Blais, J.-C.; Astruc, D. J. Am. Chem. Soc. 1997, 119, 2588-2589. doi:10.1021/ja964127t

10. Shu, C.-F.; Shen, H.-M. J. Mater. Chem. 1997, 7, 47-52. doi:10.1039/A604225B
11. Louie, J.; Hartwig, J. F.; Fry, A. J. J. Am. Chem. Soc. 1997, 119, 11695-11696. doi:10.1021/ja972806d

12. Ranasinghe, M. I.; Varnavski, O. P.; Pawlas, J.; Hauck, S. I.; Louie, J.; Hartwig, J. F.; Goodson, T., III. J. Am. Chem. Soc. 2002, 124, 6520-6521. doi:10.1021/ja025505z

13. Hagedorn, K. V.; Varnavski, O.; Hartwig, J.; Goodson, T., III. J. Phys. Chem. C 2008, 112, 2235-2238. doi:10.1021/jp7112076

14. Wong, W. W. H.; Jones, D. J.; Yan, C.; Watkins, S. E.; King, S.; Haque, S. A.; Wen, X.; Ghiggino, K. P.; Holmes, A. B. Org. Lett. 2009, 11, 975-978. doi:10.1021/ol8029164

15. Bryce, M. R.; Devonport, W.; Goldenberg, L. M.; Wang, C. Chem. Commun. 1998, 945-952. doi:10.1039/A800536B

16. Le Derf, F.; Levillain, E.; Trippé, G.; Gorgues, A.; Sallé, M.; Sebastían, R.-M.; Caminade, A.-M.; Majoral, J.-P. Angew. Chem., Int. Ed. 2001, 40, 224-227. doi:10.1002/1521-3773(20010105)40:1<224::AID-ANIE224>3.0.CO;2$\mathrm{O}$

17. Beeby, A.; Bryce, M. R.; Christensen, C. A.; Cooke, G.; Duclairoir, F. M. A.; Rotello, V. M. Chem. Commun. 2002, 2950-2951. doi:10.1039/B209765F

18. Godbert, N.; Bryce, M. R. J. Mater. Chem. 2002, 12, 27-36. doi:10.1039/B106010B

19. Astruc, D. Nat. Chem. 2012, 4, 255-267. doi:10.1038/nchem.1304

20. Boisselier, E.; Shun, A. C. K.; Ruiz, J.; Cloutet, E.; Belin, C.; Astruc, D. New J. Chem. 2009, 33, 246-253. doi:10.1039/B819604D

21. Okajima, M.; Soga, K.; Nokami, T.; Suga, S.; Yoshida, J. Org. Lett. 2006, 8, 5005-5007. doi:10.1021/ol061647c

22. Nokami, T.; Ohata, K.; Inoue, M.; Tsuyama, H.; Shibuya, A.; Soga, K.; Okajima, M.; Suga, S.; Yoshida, J. J. Am. Chem. Soc. 2008, 130, 10864-10865. doi:10.1021/ja803487q

23. Okajima, M.; Soga, S.; Watanabe, T.; Terao, K.; Nokami, T.; Suga, S.; Yoshida, J. Bull. Chem. Soc. Jpn. 2009, 82, 594-599. doi:10.1246/bcsj.82.594

24. Terao, K.; Watanabe, T.; Suehiro, T.; Nokami, T.; Yoshida, J. Tetrahedron Lett. 2010, 51, 4107-4109. doi:10.1016/j.tetlet.2010.05.140

25. Nokami, T.; Watanabe, T.; Musya, N.; Suehiro, T.; Morofuji, T.; Yoshida, J. Tetrahedron 2011, 67, 4664-4671. doi:10.1016/j.tet.2011.04.065

26. Nokami, T.; Watanabe, T.; Terao, K.; Soga, K.; Ohata, K.; Yoshida, J. Electrochemistry 2013, 81, 399-401. doi:10.5796/electrochemistry.81.399

27. Nokami, T.; Watanabe, T.; Musya, N.; Morofuji, T.; Tahara, K.; Tobe, Y.; Yoshida, J. Chem. Commun. 2011, 47, 5575-5577. doi:10.1039/C1CC10923E

28. Nokami, T.; Musya, N.; Morofuji, T.; Takeda, K.; Yoshida, J. In Proceedings of the PRiME 2012, Honolulu, HI, Oct 5-12, 2012; The Electrochemical Society: Pennington, NJ, 2012; Abstract \#2079.

29. Olah, G. A.; Krishnamurti, R.; Prakash, G. K. S. Friedel-Crafts Alkylations. In Comprehensive Organic Synthesis; Trost, B. M., Ed.; Pergamon Press: Oxford, 1991; Vol. 3, pp 229-339.

30. Littke, A. F.; Fu, G. C. Angew. Chem., Int. Ed. 1998, 37, 3387-3388. doi:10.1002/(SICI)1521-3773(19981231)37:24<3387::AID-ANIE3387>3 .0.CO;2-P

31. Yoshida, J.; Suga, S.; Suzuki, S.; Kinomura, N.; Yamamoto, A.; Fujiwara, K. J. Am. Chem. Soc. 1999, 121, 9546-9549. doi:10.1021/ja9920112

32. Suga, S.; Suzuki, S.; Yamamoto, A.; Yoshida, J. J. Am. Chem. Soc. 2000, 122, 10244-10245. doi:10.1021/ja002123p 
33. Suga, S.; Okajima, M.; Fujiwara, K.; Yoshida, J. J. Am. Chem. Soc. 2001, 123, 7941-7942. doi:10.1021/ja015823i

34. Suga, S.; Watanabe, M.; Yoshida, J. J. Am. Chem. Soc. 2002, 124, 14824-14825. doi:10.1021/ja028663z

35. Yoshida, J.; Suga, S. Chem. - Eur. J. 2002, 8, 2650-2658. doi:10.1002/1521-3765(20020617)8:12<2650::AID-CHEM2650>3.0.C O;2-S

36. Suga, S.; Nishida, T.; Yamada, D.; Nagaki, A.; Yoshida, J. J. Am. Chem. Soc. 2004, 126, 14338-14339. doi:10.1021/ja0455704

37. Nagaki, A.; Kawamura, K.; Suga, S.; Ando, T.; Sawamoto, M.; Yoshida, J. J. Am. Chem. Soc. 2004, 126, 14702-14703. doi:10.1021/ja044879k

38. Okajima, M.; Suga, S.; Itami, K.; Yoshida, J. J. Am. Chem. Soc. 2005, 127, 6930-6931. doi:10.1021/ja050414y

39. Maruyama, T.; Suga, S.; Yoshida, J. J. Am. Chem. Soc. 2005, 127, 7324-7325. doi:10.1021/ja0511218

40. Nagaki, A.; Togai, M.; Suga, S.; Aoki, N.; Mae, K.; Yoshida, J. J. Am. Chem. Soc. 2005, 127, 11666-11675. doi:10.1021/ja0527424

41. Suga, S.; Matsumoto, K.; Ueoka, K.; Yoshida, J. J. Am. Chem. Soc. 2006, 128, 7710-7711. doi:10.1021/ja0625778

42. Maruyama, T.; Mizuno, Y.; Shimizu, I.; Suga, S.; Yoshida, J. J. Am. Chem. Soc. 2007, 129, 1902-1903. doi:10.1021/ja068589a

43. Ashikari, Y.; Nokami, T.; Yoshida, J. J. Am. Chem. Soc. 2011, 133, 11840-11843. doi:10.1021/ja202880n

44. Ashikari, Y.; Nokami, T.; Yoshida, J. Org. Lett. 2012, 14, 938-941. doi:10.1021/ol203467v

45. Ashikari, Y.; Nokami, T.; Yoshida, J. Org. Biomol. Chem. 2013, 11, 3322-3331. doi:10.1039/c3ob40315g

46. Ashikari, Y.; Shimizu, A.; Nokami, T.; Yoshida, J. J. Am. Chem. Soc. 2013, 135, 16070-16073. doi:10.1021/ja4092648

47. Yoshida, J.; Ashikari, Y.; Matsumoto, K.; Nokami, T. J. Synth. Org. Chem., Jpn. 2013, 71, 1136-1144. doi:10.5059/yukigoseikyokaishi.71.1136

48. Nelson, R. F.; Adams, R. N. J. Am. Chem. Soc. 1968, 90, 3925-3930. doi:10.1021/ja01017a004

49. Diallo, A. K.; Daran, J.-C.; Varret, F.; Ruiz, J.; Astruc, D. Angew. Chem., Int. Ed. 2009, 48, 3141-3145. doi:10.1002/anie.200900216

50. Diallo, A. K.; Absalon, S.; Ruiz, J.; Astruc, D. J. Am. Chem. Soc. 2011, 133, 629-641. doi:10.1021/ja109380u

\section{License and Terms}

This is an Open Access article under the terms of the Creative Commons Attribution License (http://creativecommons.org/licenses/by/2.0), which permits unrestricted use, distribution, and reproduction in any medium, provided the original work is properly cited.

The license is subject to the Beilstein Journal of Organic Chemistry terms and conditions: (http://www.beilstein-journals.org/bjoc)

The definitive version of this article is the electronic one which can be found at: doi:10.3762/bjoc. 10.326 